\title{
The Research Into Morphogenesis Patterns of Residential Planning Units in the Early 21st Century
}

\author{
Irina Fedchenko ${ }^{1,2, *}$
}

\begin{abstract}
${ }^{1}$ Scientific Research Institute of Theory and History of Architecture and Urban Planning (NIITIAG), Branch of the Federal State Budget Institution "Central Scientific-Research and Project Institute of the Construction Ministry of Russia", Moscow, Russia

${ }^{2}$ Institute of Architecture and Design, Siberian Federal University, Krasnoyarsk, Russia

*Corresponding author.Email: ifedchenk@inbox.ru
\end{abstract}

\begin{abstract}
At the beginning of the 21st century, the dynamics of modern cities reform the understanding of the development of residential facilities. Increasing mobility, multifunctionality, problems of social stratification, segregation, as well as the growing dynamics of functional integration of production activities in the living environment and the formation of socio-ecological worldview in the society lead to a change in residential areas. The global practice of urban planning witnesses the newest volumetric and planning solutions in design projects of living environment. There is a development of new structural components of public spaces, change in social and functional characteristics of the dwelling architecture, all of which are of particular interest to the modern theory of urban planning. The article summarizes the patterns of urbanized territories of large cities, affecting the emergence of new forms of residential planning units in the early 21 st century. It also characterizes the modern principles of morphogenesis in residential areas. The article builds on the results of on-site investigation of residential planning units in Russia, Germany, USA; the results of the analysis of literary sources, project proposals of the most significant examples of modern residential planning units.
\end{abstract}

Keywords: urban planning, urban morphology, residential planning units

\section{INTRODUCTION}

In civil society, the modern problems of overpopulation and shrinking cities dictate the need for qualitative transformation of living environment for the creation of conflict-free, safe, comfortable and socioecological space for activity of people, regardless of their position in the social structure. The problems of social stratification, segregation, migration, as well as the growing dynamics of functional transformation, formation of socio-ecological worldview in society lead to a change in the morphology of residential areas $[1,2$, $3,4]$. The categories of mobility and accessibility are critical for ensuring normal functioning of a modern city $[5,6,7,8]$. In the theory and practice of urban planning, there is a search for functional and planning solutions for adaptation of the living environment to modern urban processes. The development of the socioecological worldview is being shaped by residential units such as community of communities. The dynamics of functional processes lead to the emergence

*This paper was funded by the Program of Fundamental Researches of the Ministry of Construction, Housing and Utilities of the Russian Federation and the Russian Academy of Architecture and Construction Sciences 2020, the Research Project 1.5.3. of multifunctional residential cores in a large city. The aspiration for diversity of activity forms shapes mix-use residential units. In modern cities, there is a convergence of transport, labor and housing. In addition, concepts of combining a commercial zone with a transfer hub are being developed $[9,10,11,12]$.

Relevance of the study is determined by the search for project ideas in the sphere of developing living environment in response to the demands of modern society and social processes that take place in an urbanized environment. The purpose of the study is to identify morphogenetic patterns of the living environment, formed as a result of dynamic life processes in the early $21^{\text {st }}$ century.

\section{INVESTIGATION OF DYNAMIC PROCESSES IN CITIES, AFFECTING THE MORPHOLOGY OF RESIDENTIAL AREAS}

Urban morphology refers to the study of urban forms that focuses on the formation and transformation of urban forms of cities, towns, and villages over time; their spatial patterns at different scales; and physical characteristics to inform appropriate urban interventions to promote sustainable urban development 
$[13,14]$. In philosophy, pattern is a relatively stable and regular interaction between a phenomena and objects of reality that emerge in the processes of change and development. The morphogenetic patterns in urbanized areas are manifested as a result of the dynamics of urban development, aggravation of social and environmental problems, expansion of cultural diversity, as well as the emergence of new modes of transport and technologies in modern society.

Methods of research include analysis and systematization of domestic and foreign theoretical studies in the field of urban development of residential planning units in the context of modern dynamic processes of urban life. In this article recognizes the following categories of dynamic processes in urban life, affecting the morphology of residential planning units:

- Socio-economic processes: issues of inequality in a city, problems of social stratification and socio-territorial segregation are studied in the works of Kiyanenko, Ptichnikova. Development of self-management in residential planning units was studied in the works of authors: Shomina and Sanoff. The problems of urban planning regulation and land survey of residential development are studied in the works of Vysokovsky, Trutnev, Alekseyev, Krasheninnikov. The mechanisms of participatory decision-making in designing and reconstructing residential planning units have been studied by Yeshchina, Filanova.

- Functional processes of urban transformation: categories of mobility and availability in the spatial organization of residential development have been studied in the works of Krainaya. In the group of works by Kukina, Fedchenko, they develop concepts of new morphotypes of residential development as cores of growth for economic stability of regions. The formation of a balanced transportation system, including the organization of intermodal system of public transport that forms residential areas have been studied in the works of Condon, Bae.

- Socio-cultural phenomena reflected in the urban form. Socio-ecological foundations of forming residential areas are defined in the works of Nefedov, Unagaeva, Krasilnikova and others. Culturological tendencies of urban gardening in the formation of communities were studied in the works of Müller, Ulpu Kojo. The development of natural processes of formation of ethnic areas, including the problem of emigration processes in Moscow have been studied by Vendina. In addition, Rapoport analyses the philosophical foundations of relations between society and urban environment.

\section{ANALYSIS OF MODERN MORPHOGENETIC TRENDS IN URBAN RESIDENTIAL AREAS}

As the analysis of modern design projects shows, residential areas represent different models of space organization. There develop design ideas of functionally mixed use of territory; inclusion of transfer hubs in a living environment; closed or gated socioeconomic communities and, at the same time, sociallyintegrated residential units. In general, there is a process of global search for combining design and planning ideas.

\section{A. Aspiration for diversity of forms of residential development}

In the early $21^{\text {st }}$ century, due to the growing pace of social stratification, social and territorial segregation in modern cities, there form isolated residential entities gated communities comprised of people of a certain socio-economic status. Such residential units are usually physically isolated and presented as subordinate residential areas of a certain enclave. Gated communities form in many large cities. As a response to the problem of social and territorial segregation, urban planning theory raises issues of forming socially integrated residential units, which include various styles of housing architecture and types of ownership on variably sized plots. Kiyanenko notes that such neighborhoods should contain differently priced residential buildings for families belonging to diverse social groups, which will contribute to the formation of social stability of settlements [15]. Today, the projects of residential planning units include mix-use territories: from an individual house to a sectioned one. The desire for diversity of activities and, consequently, types of residential development is manifested both in the overhaul of residential neighborhoods constructed in 1960-1970s [16, 17, 18] and in the latest projects of residential planning units. For example, the Riedberg development district in Frankfurt (Germany) is a combination of residential blocks of different architectural types, united by a system of recreational facilities. Riedberg is the largest district on the outskirts of Frankfurt am Main and one of the largest urban development projects in Germany. The blocks vary considerably in their functions and types of housing. The Riedberg West Wing block (southeast) consists of individual and terraced midrise houses and mixed local community condominiums with their own public spaces. The Altkönigblick (northwest) and Bonifaciumbrunnen (northeast) blocks consist of twoapartment houses, townhouses, condominiums, town villas, a condominium complex, houses for inclusive living. The eastern-side block - Schöne Aussicht consists of individual, row houses, and townhouses with gardening areas. The central block of Rosa Luxemburg is formed by sectioned mixed-use houses, shopping centers, market, medical center and a 
separately planned campus of Goethe University [19]. By 2020, the district is to be completed. The cultural and social infrastructure of public educational institutions, including more than ten kindergartens, two

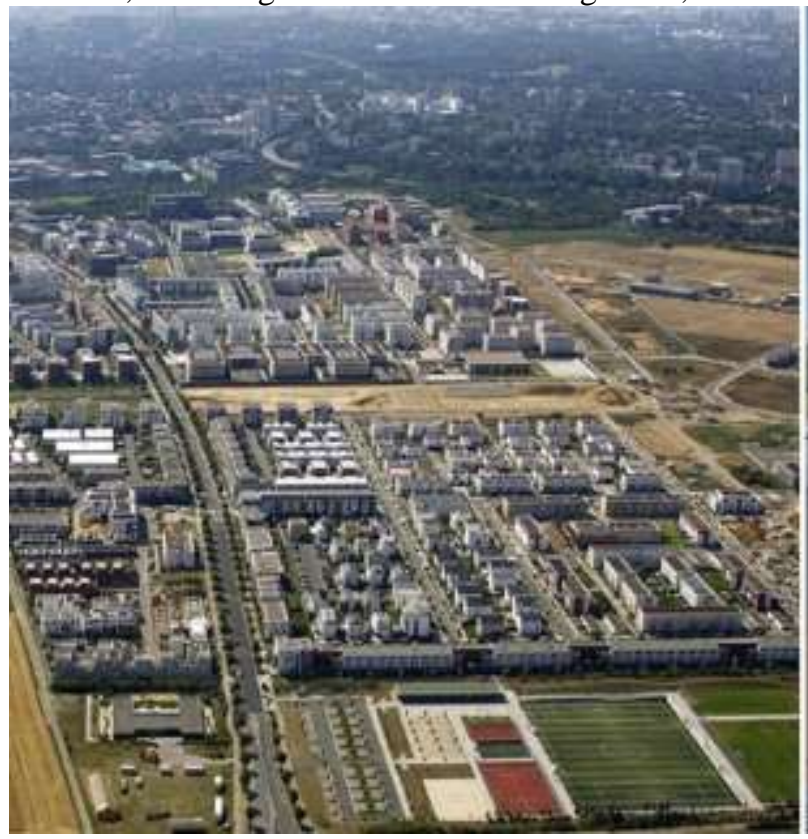

primary schools, a secondary school, as well as religious spaces and work places will also be fully functional [20] ("Fig. 1").

Fig. 1. General view and layout of the Riedberg district master plan in Frankfurt. View of the Riedberg West Wing block in the Riedberg district (south-east) [21] (photo by I. Fedchenko).

\section{B. Development of residential planning units through participatory planning and local self-government}

In the early $21^{\text {st }}$ century, an important step is made in the development of cities which is the transition from monologue to dialogue among professional planners, business representatives, officials and citizens. In residential areas, partnerships are established for the purpose of coordinated prospective development of planning units. There develop local associations of citizens, both formal such as local administration, territorial self-government bodies, public-private partnerships, and informal neighborhood communities, acting at the initiative of citizens. In order to consolidate neighborhood ties within residential planning units of North America, China, Eastern Europe, and partly in Russia, planners design neighborhood centers, and residential areas, managed by local residents. In the task of uniting the local community, the joint enhancement of public spaces in residential areas is of particular importance. For example, "Belye Tsvety" Boulevard was created in Kazan (Republic of Tatarstan, Russia) together with the inhabitants of the residential district. In 2018 the project authors (Project Group 8) held discussions in different formats - they met with local residents, interested communities, service organizations, entrepreneurs, and organized creative workshops with schoolchildren ("Fig. 2"). At the initiative of local residents, a development plan for the boulevard was developed within the framework of the Public Space Development Programme of the Republic of Tatarstan "Zhil'e i Gorodskaya Sreda" (Housing and Urban Environment). The main task was to identify all parties interested in the territory development. 


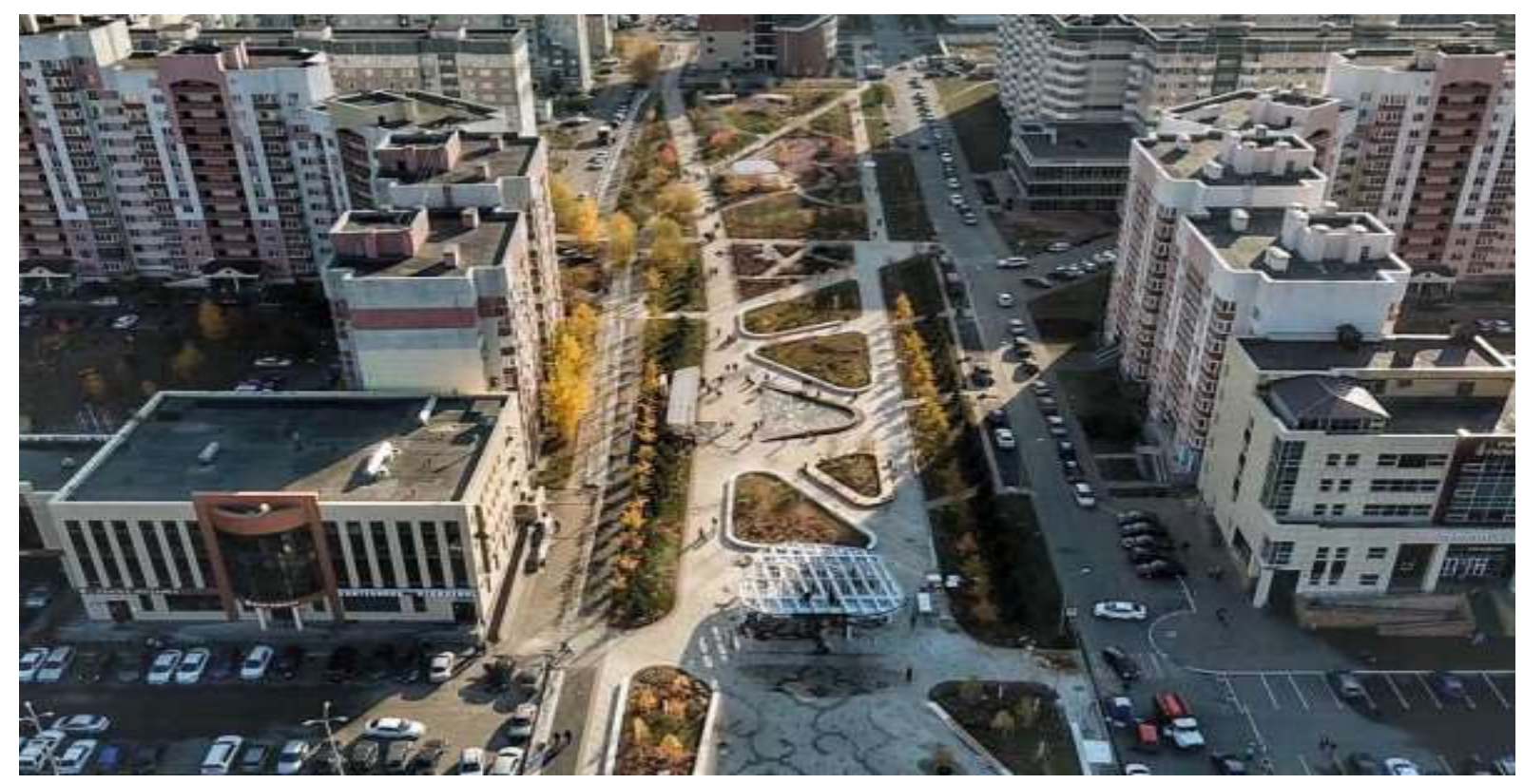

Fig. 2. General view of "Belye Tsvety" Boulevard. Kazan (URL: http://park.tatar/abs).

\section{Dynamics of formation of multifunctional residential cores in a large city}

In modern times, the dynamics of integrating production activities into the living environment is growing. Housing is getting physically closer to the dominant urban functions, previously not typical for residential development. Multifunctional residential planning units as drivers of growth of a large city emerge within the framework of new development, as well as during reconstruction of existing territories. In the modern practice of urban development, there appear projects aimed at the revitalization of unprofitable areas through mixing of functions. For example, an urban planning project "Noviy Port" for 7000 residents in Krasnoyarsk features a new mixed-function residential area with large business, shopping and sports centers, a river transport station and so forth. Noviy Port is planned to be located on the territory of former industrial sites in Krasnoyarsk subject to redevelopment: Oil depot, River port, Realbaza. The transformation of these territories into modern residential areas implies the creation of an active social and business zone ("Fig. 3").

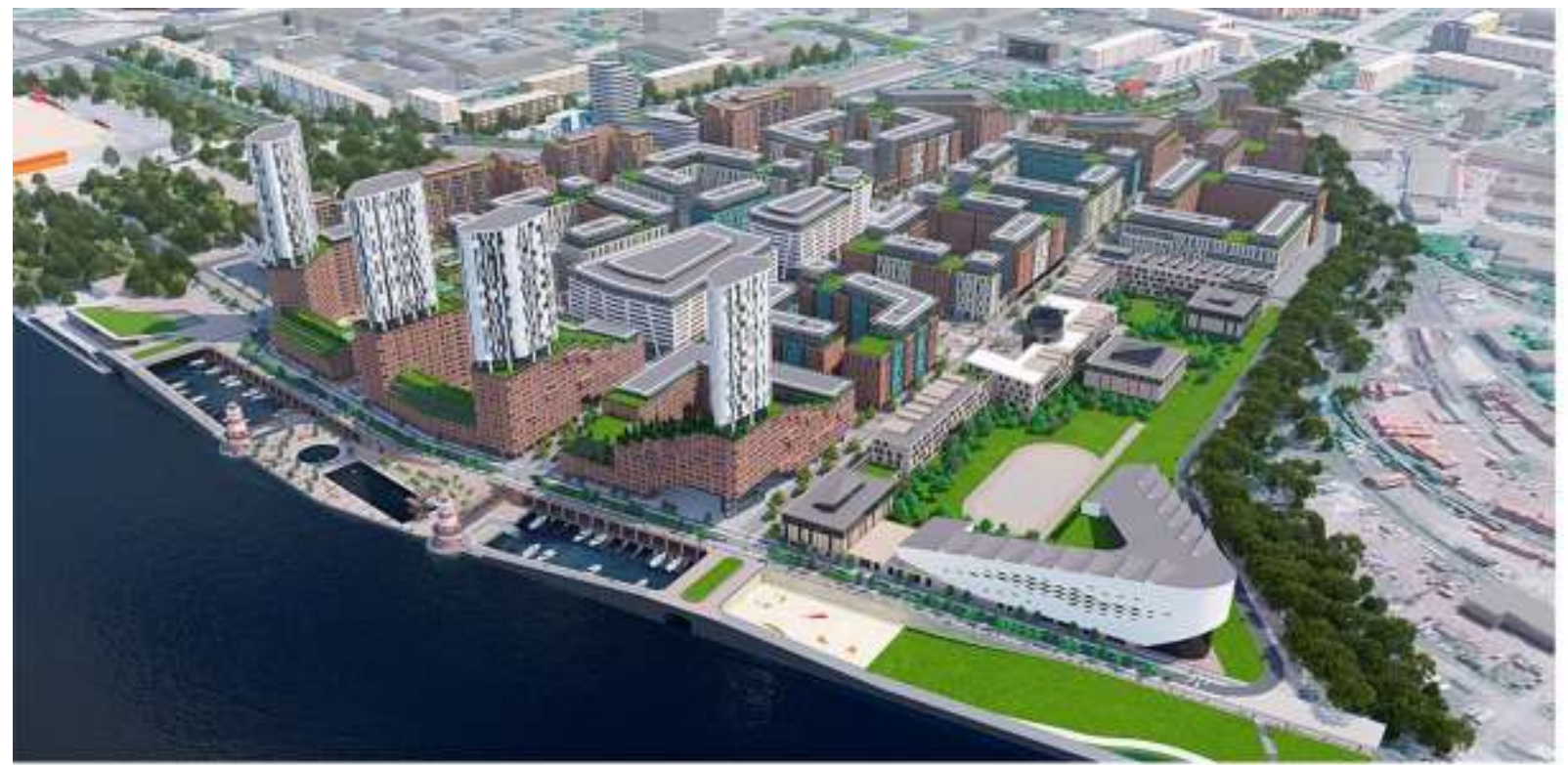

Fig. 3. Project for conversion of industrial enterprises into the "Noviy Port" residential area in Krasnoyarsk. OOO "KPM A-2" (URL: http://www.proa2.ru/projects/noviy-port). 


\section{Formation of transport-oriented residential areas}

One of the peculiar modern trends in the formation of residential environment is merging transfer hubs with residential development. The purpose of such a merger is the provision of mobility and accessibility: the provision of a transportation link with a city, in order to reduce dependence on personal vehicles through the use of multimodal systems of public transport [22]. There forms a new planning type of residential development with a pronounced density of functions of the public transport junction located in the geometric center of residential education [23] ("Fig. $4 ")$.

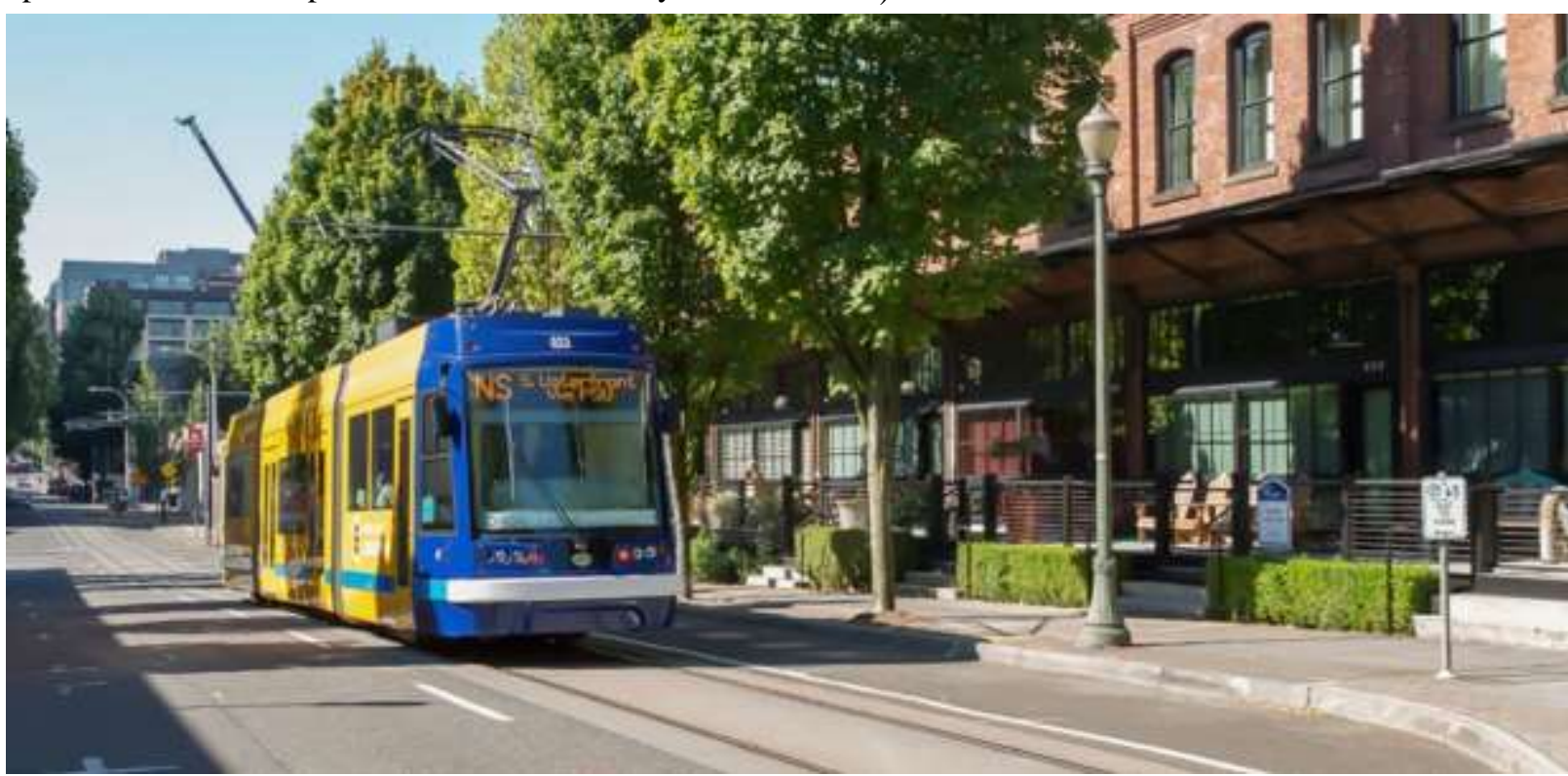

Fig. 4. Transit-oriented district (TOD) concept PerlDistrict District, Portland, USA (Photo by I. Fedchenko).

\section{E. Ecologically oriented initiatives in the development of the living environment}

Among modern projects one can define eco-oriented dwelling formations, which, based on the general structure, represent a group of local areas connected by the system of public spaces with collective gardens. The main idea of the eco-oriented district is life in harmony with nature where the man-made environment creates an educational component aimed at fostering an ecological culture, new ways of thinking and creativity. The landscape of residential areas reflects social and cultural trends. For example, the Intercultural Gardens in Hannover is part of the German strategy for sustainable social development. The intercultural garden brings together social communities from different countries, using urban space to improve the microclimate in the neighborhood.

Ecologically-oriented planning of residential units is based on the preservation of natural water systems, native plant species, and, if possible, ecological niches of the animal world characteristic for the area. Territories of residential planning units are being subject to effective landscape and urban planning zoning in order to continuously maintain biodiversity beyond the unit (reconstruction projects of neighborhoods in East Germany, the eco-communities of Northern Europe, green corridors in the neighborhoods of America). Thus, the reconstruction project of Noisette community (Charleston, South Carolina, USA) is built on the idea to preserve the natural system of green spaces, and restore the hydrological system of the Cooper River tributaries, wetlands along the bay, and flood meadows. The project defines the river system areas as areas with special status and establishes control over animal migration processes. In the structure of the neighborhood there are linear buffer parks where the main recreational facilities are located ("Fig. 5"). 

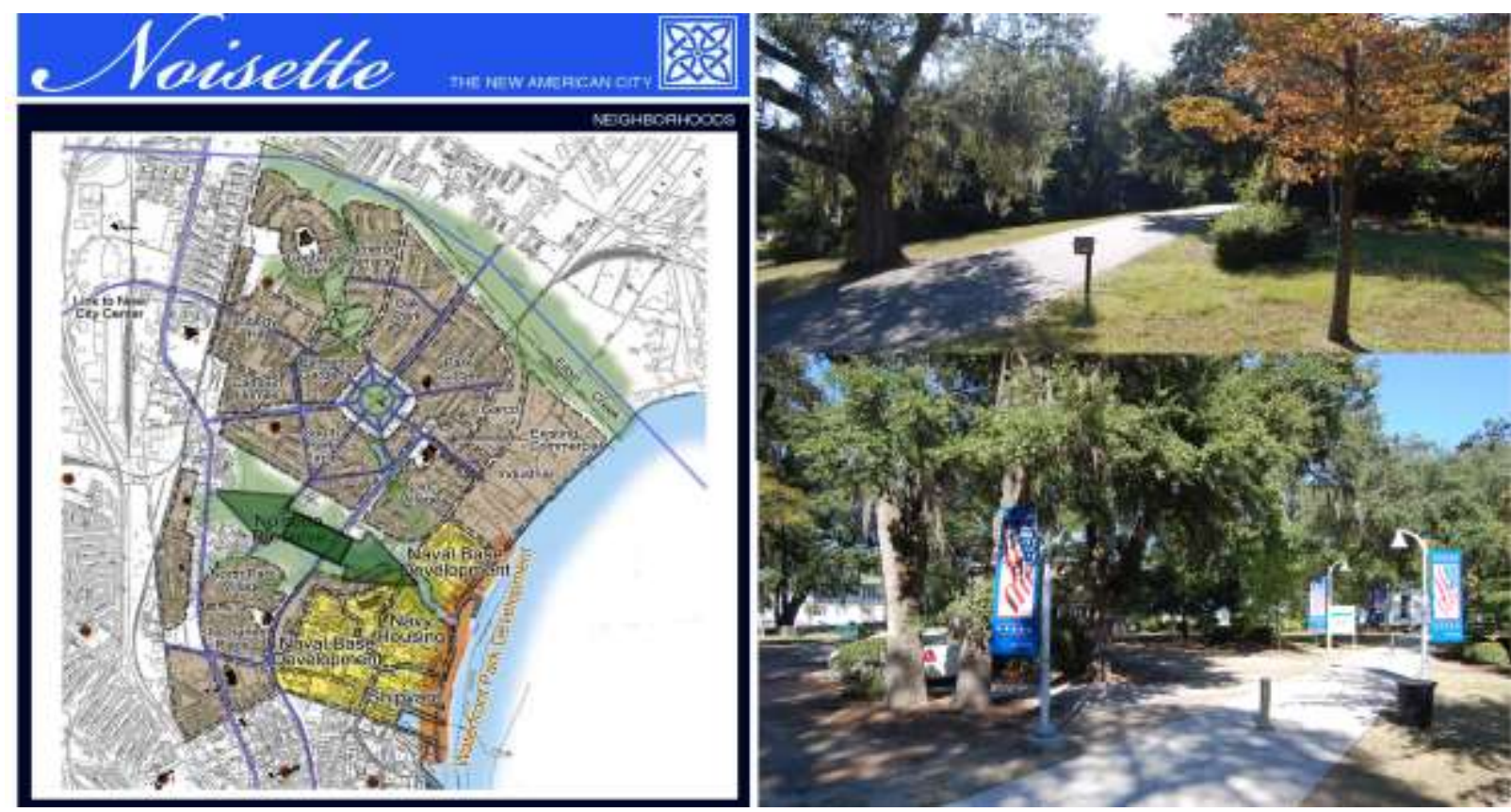

Fig. 5. Continuous green system in Noisette community, Charleston, South Carolina, USA (photo by I. Fedchenko).

\section{CONCLUSION}

The emergence of unforeseen processes in a modern city leads to the transformation of planning structure of residential areas. Morphological changes affect both buildings and open spaces. In the modern practice of urban planning, new morphotypes of the living environment are formed due to the dynamic processes of life. As a result of social and territorial stratification and segregation, gated communities are being formed. A socially integrated residential unit embodies the ideas of mixing the population of different affluence on the way to a socially sustainable city of the future. The dynamics of functional processes and integration of production activities into the residential environment give rise to the multifunctional residential cores in a large city - mix-use districts. The desire for diversity of forms of activity forms the residential units of mixed types of development. Mechanisms of collective control and management over territory development form a new type of residential planning units - community. Development of ecological consciousness of residents and landscape-ecological approach to territory development form residential units of "eco-area" type. In modern cities there is a convergence of transport, labor and housing. The concepts of combining commercially active zone with transfer hubs are being introduced. The typology of modern residential environment morphotypes may become the basis for the scenario method of residential area planning, which will ensure the optimal use of city territory in the future.

\section{References}

[1] M.P. Nazarova, Sociocultural archetypes in the structure of architectural space, Volgograd: VolgGASU, 2011, 237 p. [in Russian]

[2] G.A. Ptichnikova, A.V. Antyufeev, New morphotypes of architectural space in modern cities in: Sociology of City, 2014, no. 2, pp. 5-19. [in Russian]

[3] K.V. Kiyanenko, Sociology of sustainability versus segregation architecture in: Architecton. Proceedings of Higher Education, 2015, no. 1 (49), pp. 32-49. [in Russian]

[4] S. Low, The Edge and the center: Gated communities and the discourse of urban fear in: American Anthropologist, 2001, vol. 103 , no. 1 , pp. $45-58$

[5] I.G. Fedchenko, Planned residential units: New development trajectories in: Youth, Science, Solutions: Ideas and Prospects (YSSIP-2016): Proceedings of the III International Young Researchers Conference "Youth, Science, Solutions: Ideas and Prospects", 2017, vol. 1800. URL: http://elib.sfukras.ru/handle/2311/69593 (accessed: 17.03.2020).

[6] I.V. Kukina, Regulations of the "free development" of the urbanized territories in the planned agglomerations in foreign countries in: Academia. Architecture and Construction, 2011, no. 3, pp. 81-86. [in Russian].

[7] N.P. Krainyaya, To the search for sociality in the shaping of urban development in: Academia. Architecture and Construction, 2009, no 2, p. 73. [in Russian]

[8] P.M. Condon, Seven Rules for sustainable communities: design strategies for the post-cardon world, Washington, DC: Island Press, 2000, 216 p.

[9] C. Bae, Orenco station, Portland, Oregon: A Successful transit oriented development experiment? in: Transportation Quarterly, 2002, vol. 56, no. 3, pp. 9-18.

[10] G.A. Ptichnikova, A.V. Antyufeev, op. cit.

[11] I.G. Fedchenko, Planned residential units: New development trajectories, op. cit.

[12] P.M. Condon, op. cit. 
[13] V. Oliveira, Urban morphology: An Introduction to the study of the physical form of cities, Springer, 2016, $192 \mathrm{p}$.

[14] F. Chen, Urban morphology and citizens' life // Encyclopedia of quality of life and well-being research / ed. Michalos A.C., Dordrecht: Springer, 2014.

[15] K.V. Kiyanenko, op. cit. E.E. Krasilnikova, V.A. Rusanov, L.A. Kuzina, MODERN TENDENCIES IN FORMATION OF FLEXIBLE AND SUSTAINABLE RESIDENTIAL STRUCTURES in: Bulletin of Volgograd State University of Architecture and Civil Engineering. Series: Construction and Architecture, 204, no 36(55), pp. 275-283. [in Russian]

[16] P. Metspalu, Revisiting the role of architects in planning largescale housing in the USSR: the birth of socialist residential districts in Tallinn, Estonia, 1957-1979 in: Planning Perspectives, 2018, no. 33, pp. 335-361.

[17] D. Karien, Residential satisfaction in housing estates in European cities: A Multi-level research approach in: Housing Studies, 2011, vol. 4, no. 26, pp. 479-499.

[18] I.V. Kukina, I.G Fedchenko, Morphological development of the microdistricts under the pressure of the post-socialist transformations: Case studies of Siberian cities in: Proceedings of the "International conference on cities and change: Three decades of post-socialist transition 1989-2019" / eds. N. Camprag, A. Suri, TU prints, TU Darmstadt, 2019, pp.137-147.

[19] I.G. Fedchenko, Modern patterns of formation of residential planning units in: Academia. Architecture and Construction, 2019, no. 4, pp. 75-82. [in Russian]

[20] "Der Frankfurter Riedberg: Stadtentwicklung für das 21. Jahrhundert" / eds. C. Kaufmann, P. Michael, Berlin: JOVIS Publishers, 2018, 240 p. [In German]

[21] D. Karien, Residential satisfaction in housing estates in European cities, op. cit.

[22] G.A. Ptichnikova, A.V. Antyufeev, op. cit.

[23] C. Bae, op. cit. 